\title{
EXAMINATION OF THERMAL WORK OF ELECTRIC CHAMBER FURNACE TO THERMAL PROCESSING
}

\author{
Marta Kowalik-Wolska', Jarosław Boryca' \\ 1 Department of Industrial Furnaces and Environmental Protection, Faculty of Production Engineering and \\ Materials Technology, Czestochowa University of Technology, 42-200 Częstochowa, Al. Armii Krajowej 19, \\ Poland, e-mail: kowalikmj@wp.pl; jboryca@op.pl
}

Received: 2015.07.20

Accepted: 2015.08.05

Published: 2015.09.01

\begin{abstract}
The improvement of effectiveness of work furnaces depends on increasing the efficiency as well as the decrease the elementary consumption of energy. The character of the analyzed electric chamber furnace to thermal processing in work was introduced. over the discussed results concern the efficiencies, consumption of electric energy as well as the coefficient of elementary consumption of energy. The improvement of coefficients of furnace solutions were proposed.
\end{abstract}

Keywords: heat treatment, heating costs, heat consumption.

\section{INTRODUCTION}

One of the basic factors that determine the price and, consequently, the competitiveness of the product is the energy efficiency of the manufacturing process. The attempts should be made in any areas for which fuel and energy consumption is important to incessantly strive for reduction in energy intensity of production processes.

Reduction in energy intensity of the production process can be achieved in a number of ways, e.g. modernization of current furnaces, which are an integral part of any heat treatment department. The basic aim of such a modernization is improvement in efficiency of furnace work, which manifests mainly in the increase in their capacity, fuel efficiency (reduction in unit energy consumption) etc. The decision about starting such initiatives should be made after the analysis of thermal work of the furnace.

\section{INDICES OF THERMAL WORK OF FURNACES}

Evaluation of the efficiency of current heatgenerating equipment is based primarily on the results of thermal measurements. The results of thermal examinations are usually presented in a form of balances. The balance-based approach has numerous advantages, including $[1,2]$ :

- it allows for correctness of measurements and calculations,

- it removes the necessity of dealing with processes inside the system analysed by the balance,

- it facilitates unequivocal calculation of the efficiency of the process and relative loss that occurs in the process.

The basis for ensuring proper thermal balance is the principle of energy conservation, which says that the general equation of the balance can be expressed mathematically as [3]:

$$
E_{d}=\Delta E+E_{w}
$$

where: $E_{d}$ - energy supplied to the system,

$E_{w}$ - energy released from the system,

$\Delta E$ - change in energy of the system.

Energy balances are most often prepared with respect to the unit of charge mass and time unit. In industrial energy sector, the important condition of evaluation of the quality of utilization of energy in the processes is the index of unit energy consumption with respect to the unit of the final effect in the process [4]. For electric furnace, the 
index of unit heat (energy) consumption is calculated from the relationship:

$$
W J Z E=\frac{Q_{\text {elek. }} \cdot 3600}{m}, \mathrm{~kJ} / \mathrm{kg}
$$

where: $Q_{\text {elek }}-$ electric energy consumption, $\mathrm{kWh}$, $m$ - charge mass, $\mathrm{kg}$.

The index of unit heat consumption reflects energy intensity of the heating process, and, consequently, the quality of furnace operation. This affects the cost of the heating process, which is determined based on the current prices of electricity.

\section{FURNACE SPECIFICATIONS}

The examined resistance chamber furnace (PEKtw 1000/4) is installed in the department of heat treatment of machine parts. The department is a separate part in the technological centre of the enterprise. Electric chamber bogie hearth furnace PEKtw-1000/4) is a furnace designed for heat treatment processes, mainly for annealing at the temperature of up to $1000^{\circ} \mathrm{C}$ in air atmosphere.

Design of the furnace is presented in Figure 1. With high-quality temperature controllers, recorders and other control components, the furnace is qualified for performance and monitoring of the above technological processes. Distribution of heating elements in all the walls of heating chamber, gates and in the hearth guarantees demanded distribution of temperature in the working space of the furnace. Heating elements are made of Kanthal AF resistant strips in a corrugated shape.

Thermal insulation (brickwork) was made of high-class insulation materials in a form of mats

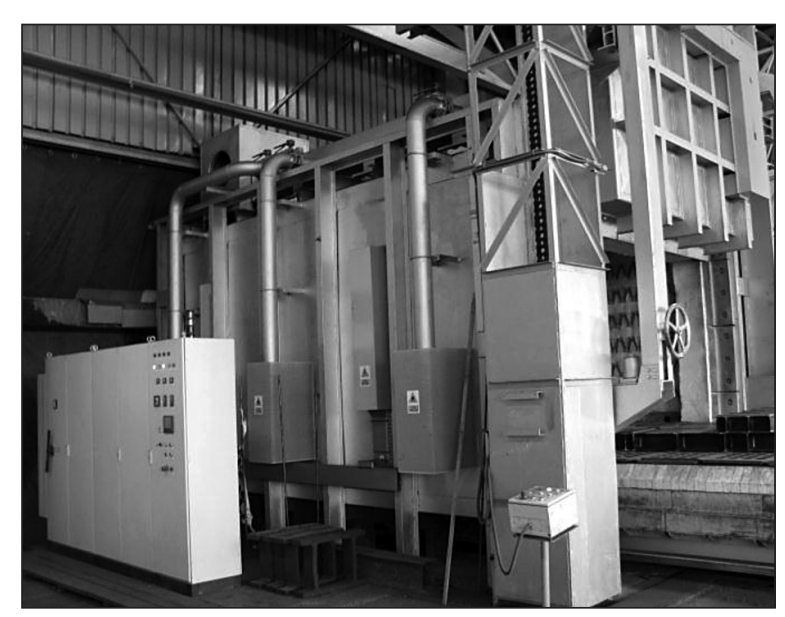

Fig. 1. Design of electric chamber furnace with a bogie hearth and fibre boards and conventional ceramic materials. Furnace hearth was made of high-quality conventional refractory and insulation materials with durability suitable to handle charge mass [5].

Technical specifications of the furnace are presented in Table 1.

Table 1. Technical specifications of the furnace [5]

\begin{tabular}{|l|c|}
\hline Maximum charge mass & $25000 \mathrm{~kg}$ \\
\hline Furnace dimensions: & \\
width & $6450 \mathrm{~mm}$ \\
height & $6780 \mathrm{~mm}$ \\
length & $7480 \mathrm{~mm}$ \\
\hline Maximum operating temperature & $1000^{\circ} \mathrm{C}$ \\
\hline Rated power & $690 \mathrm{~kW}$ \\
\hline
\end{tabular}

\section{ANALYSIS OF HEATING PROCESS}

Any heat treatment operation is characterized by a heating curve adjusted to the material and type of operation. Figures 2-4 presents selected heating curves for the furnace analysed in the study.

Operation 1 is normalizing the rods with diameter of $60 \mathrm{~mm}$ and total mass of $1600 \mathrm{~kg}$. Charge temperature was increased linearly up to the value of $860{ }^{\circ} \mathrm{C}$ for 4 hours. Then, the charge was held for 2 hours at this temperature, and, after 1.2 hours, it was cooled to the temperature of $700{ }^{\circ} \mathrm{C}$.

Operation 2 concerned interoperational annealing. The charge was provided by 2 rods with diameter of $400 \mathrm{~mm}$ and length of $4 \mathrm{~m}$. The mass of the cylinder was $3944 \mathrm{~kg}$. Charge temperature was increased linearly up to the value of $550{ }^{\circ} \mathrm{C}$ for 3 hours. Then, the charge was held for 3 hours at this temperature, and, after 4 hours, it was cooled to the temperature of $350^{\circ} \mathrm{C}$.

Operation 3 was stress relief annealing of the structure after fusion welding. The charge was a post with a mass of $3600 \mathrm{~kg}$. Charge temperature was increasing up to the value of $620^{\circ} \mathrm{C}$ for 6.5 hours. Then, the charge was held for 3 hours at this temperature, and, after $18.5 \mathrm{~h}$ it was slowly cooled to the temperature of $200^{\circ} \mathrm{C}$.

\section{ANALYSIS OF FURNACE OPERATION}

Furnace capacity and electric energy consumption was determined for heat treatment operations. The results are presented in Figures 5 and 6.

The analysis of the above figures leads to the conclusion that operations of heat treatment 


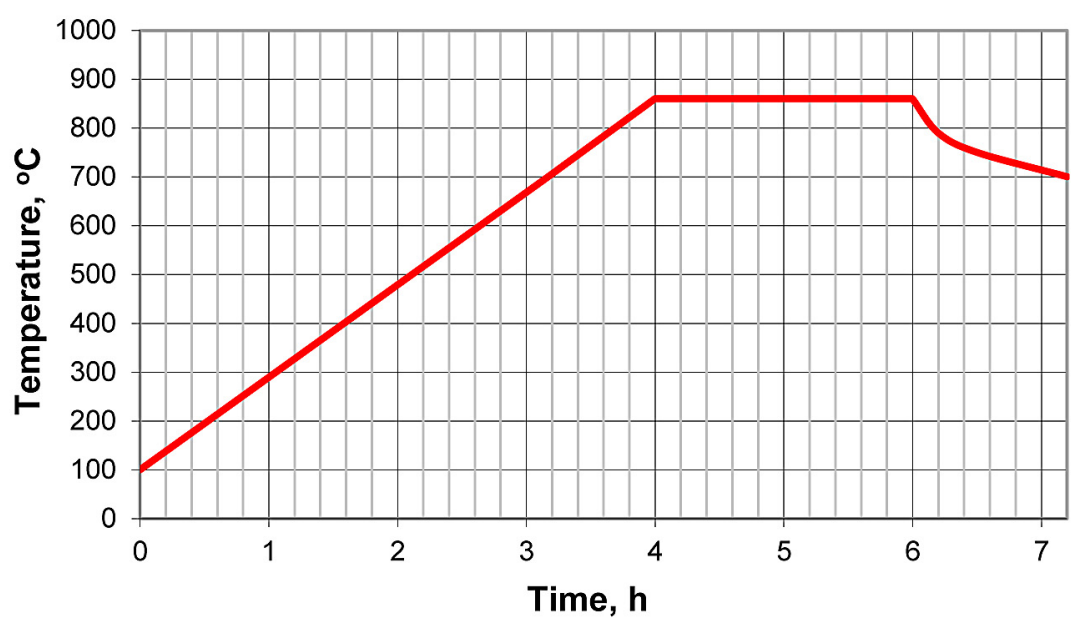

Fig. 2. Heating curves for the normalizing (operation 1)

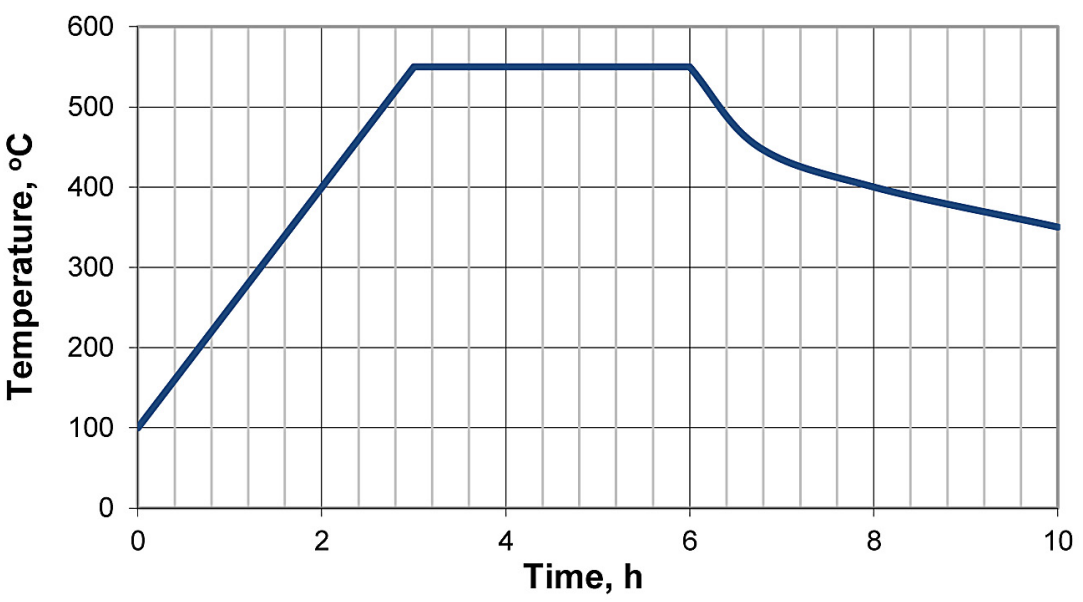

Fig. 3. Heating curves for the stress relief annealing (operation 2)

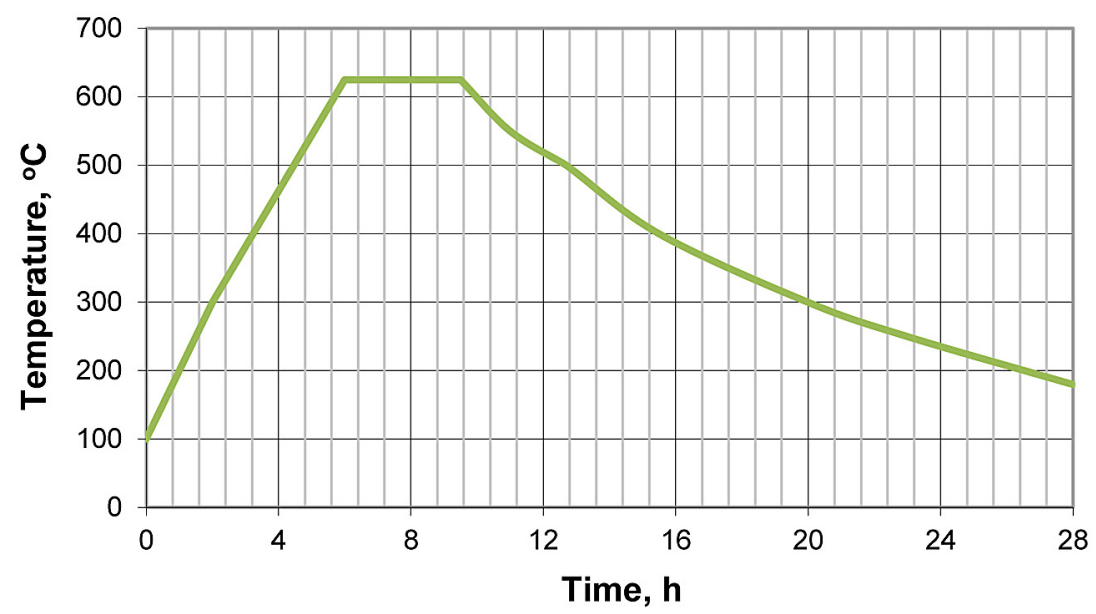

Fig. 4. Heating curves for the interoperational annealing (operation 3)

in the resistance chamber furnace are characterized by low capacity. This results from the specific nature of the heat treatment, also from the character of the department and its profile. Similar situation is observed for energy consumption.
The highest energy consumption can be observed for operations of interoperational annealing (operation 2) characterized by the lowest capacity. Comparison of operation 1 and 2 reveals that, despite substantially higher annealing temperature, with insignificantly longer duration of 


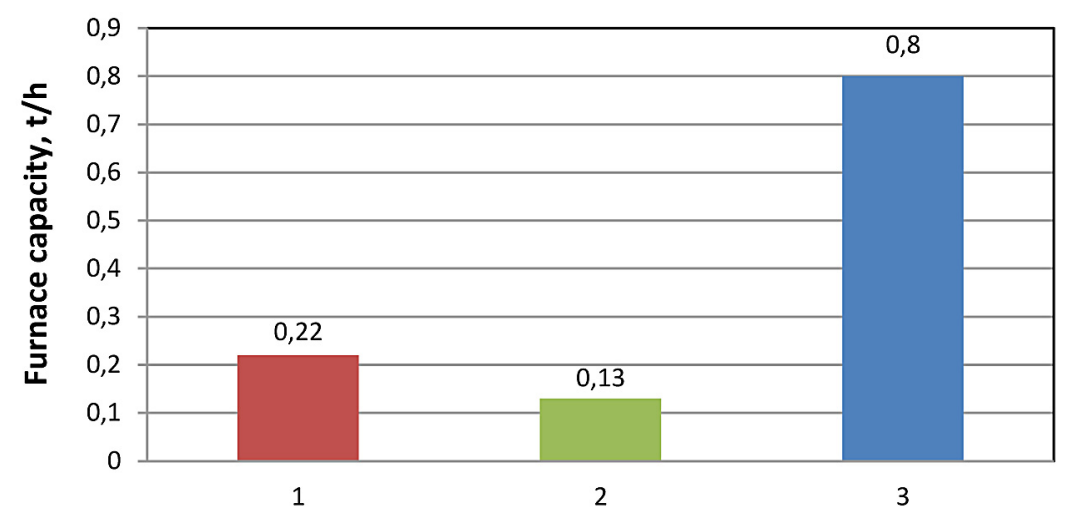

Number of analysed operations

Fig. 5. Furnace capacity for the operations analysed in the study

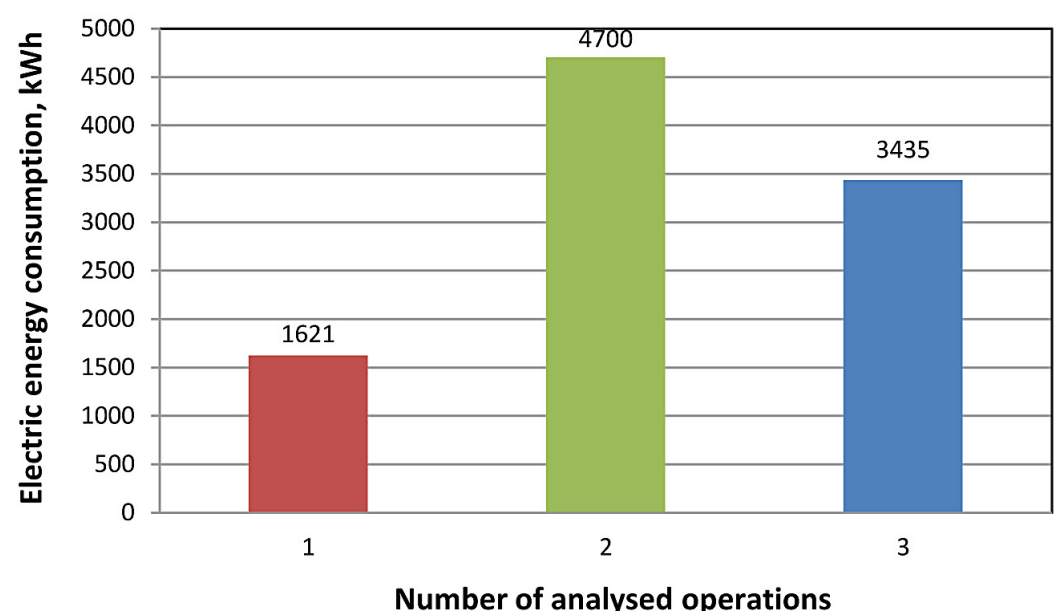

Fig. 6. Electric energy consumption for the operations analysed in the study

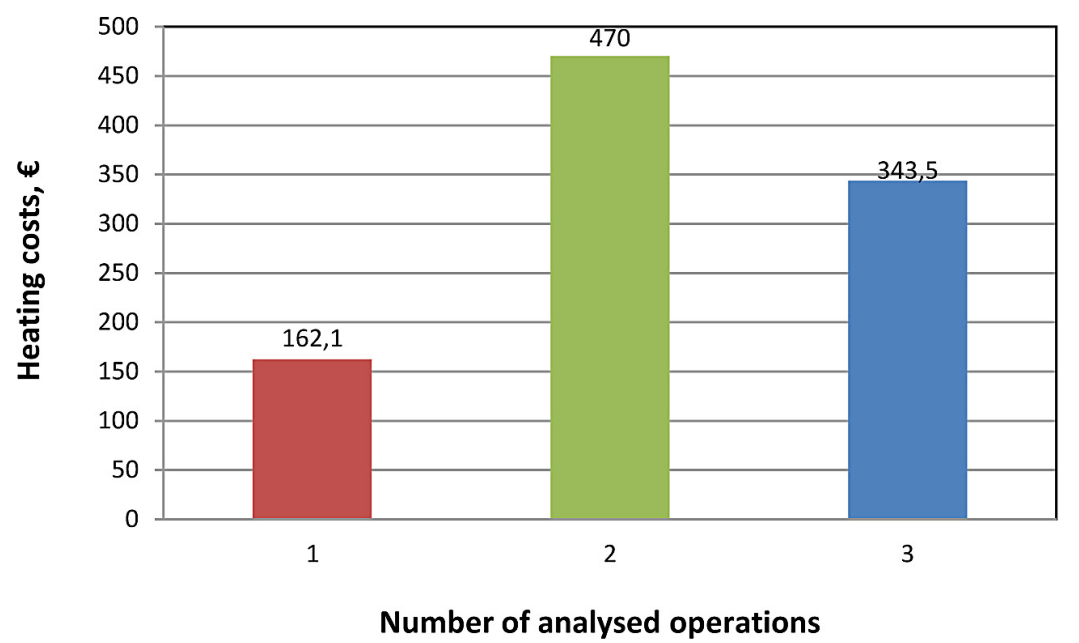

Fig. 7. Heating costs in the operations analysed in the study

the process, normalizing operation is characterized by substantially lower energy consumption. This results from the geometry of the annealed charge. In the case of normalizing, charge was provided by rods with small diameters, whereas in the case of interoperational annealing, the di- ameter of the rods was by nearly 7 times higher. Energy consumption has an effect on annealing costs of individual operations, which is presented in Figure 7.

Calculation of the heating costs were based on the electricity price of $100 € / \mathrm{MWh}[6]$. The 


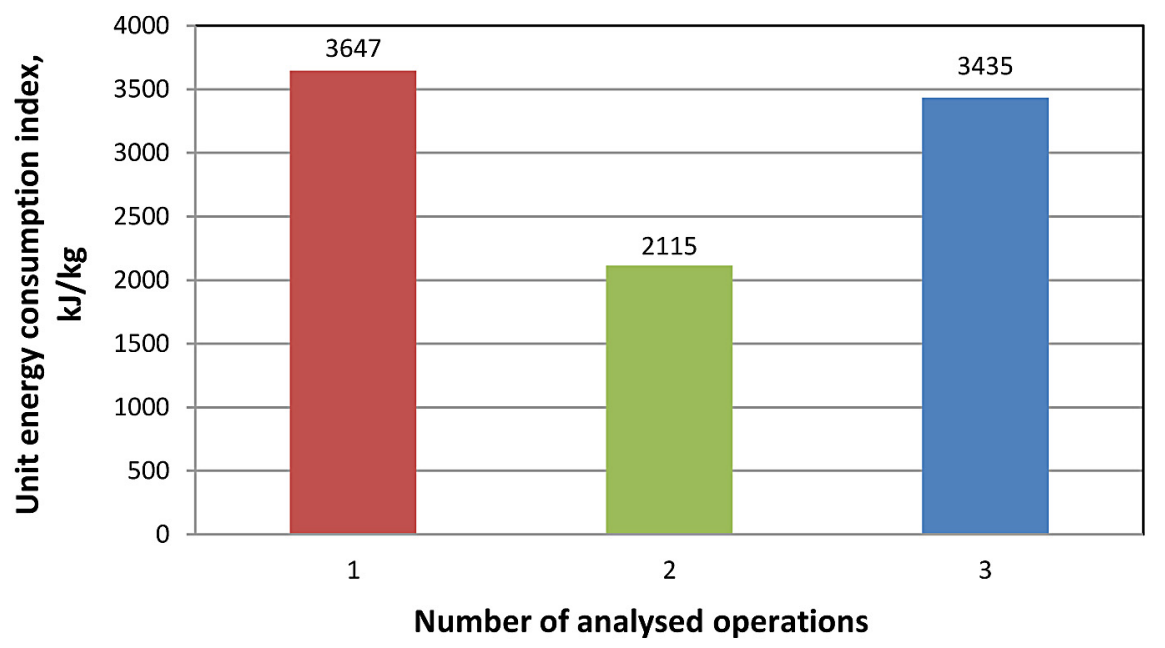

Fig. 8. Unit energy consumption index for the operations analysed in the study

costs of heating are correlated with energy consumption. Unit energy consumption index is presented in Figure 8.

Analysis of Figure 8 reveals that operation 1 (normalizing) is characterized by the highest value of the index. A slightly lower index was found for operation 3 (stress relief annealing). Despite almost twice higher energy consumption, values of unit energy consumption index for these operations are nearly comparable. This is caused by the fact that normalizing was carried out for the charge with over twice higher mass compared to stress relief annealing, with operation time being four times shorter. Furthermore, in order to heat the charge for normalizing, it was necessary to supply substantially more energy due to higher temperature the operation occurs at.

\section{CONCLUSIONS}

Chamber furnaces for heat treatment have a specific character since, despite the seasonal operation they are designed for, each heating should be adjusted to specific temperature conditions of the charge. Furthermore, an important role is also played by operation time, which depends not only on the type of treatment but also on geometrical dimensions (charge mass). This causes that it is very difficult to operate the furnace for varied heating parameters which follow one after another.

The results obtained for unit energy consumption index and heating costs lead to investigations of opportunities for the improvement of furnace operation organization, which is likely to contribute to a more efficient operation. Improved furnace operation can be achieved without much financial expenses. It is suggested that furnace operation is organized so that:

- operations of heat treatment should be planned in advance and performed in „blocks” for heating that requires similar temperature parameters,

- heating should be carried out so that it allows for rational utilization of furnace heating power,

- heating with reduced capacity requires changes in heating technologies [7, 8]. However, in the case of processes of heat treatment, the necessity of maintaining heating curves causes that reduction in energy consumption can be improved through better utilization of the working space of the furnace.

With regard to the character of the department the furnace operates in, this can be difficult to be achieved, but not impossible. With adequate financial resources, the implementation of the information system IFS $[9,10]$ can be proposed, which would substantially allow for planning furnace operation.

\section{Acknowledgements}

The co-author received a grant of the DoktoRIS project - a scholarship program for innovative Silesia region co-financed by the European Union of the European Social Fund.

\section{REFERENCES}

1. Szargut J.: Energetyka cieplna w hutnictwie. Wydawnictwo „Śląsk”, Katowice 1983. 
2. Senkara T.: Piece grzewcze w hutnictwie żelaza. „Śląsk”, Katowice 1981.

3. Michałowski M., Ciuba Z., Machniewicz J., Zięba A.: Badania i pomiary cieplne pieców w hutnictwie żelaza. „Śląsk”, Katowice 1973.

4. Górska M., Budzik R., Michalik J., Piec R.: Racjonalizacja użytkowania paliw w piecach pokrocznych Walcowni Średniej. Hutnik - Wiadomości Hutnicze nr 5, 2009, 318-324.

5. Operation and Maintenance Manual of the resistance chamber furnace PEKtw 1000/4. Materiały wewnętrzne przedsiębiorstwa.

6. Kieloch M.: Energooszczędne i małozgorzelinowe nagrzewanie wsadu stalowego. Prace Naukowe Wydziału Inżynierii Procesowej, Materiałowej i Fizyki Stosowanej, Seria Metalurgia No. 29,
Częstochowa 2002.

7. Kieloch M., Boryca J., Piechowicz Ł.: Influence of the furnace production capaity on heating consumption for industrial heating furnaces. Acta Metallurgica Slovaka, 13(3), 2007, 147-153.

8. Pudło M., Kucęba R.: The evolution of ERP systems in companies of the energetistic sector - present situation and possibilities. 3-rd conference IBIS'01 Global Information Society, Agency for Business Development, Malmö-Copenhagen, 2830 September 2001.

9. Kiełtyka L., Kucęba R., Jagodziński M., Pudło M.: Zintegrowany system zarządzania przedsiębiorstwem. IFS Applications. Ćwiczenia Z obsługi, wybrane moduły, Wyd. Politechniki Częstochowskiej, Częstochowa 2003. 